\title{
Stock dynamic of the Iberian sardine (Sardina pilchardus, W.) and its implication on the fishery off Galicia (NW Spain)*
}

\author{
PABLO CARRERA ${ }^{1}$ and CARMELA PORTEIRO ${ }^{2}$ \\ ${ }^{1}$ Museo do Mar de Galicia, Avenida Atlántida 160, 36280 Vigo, Spain. E-mail: pablo.carrera@ terra.es \\ ${ }^{2}$ Instituto Español de Oceanografía. Centro Oceanográfico de Vigo. Apdo. 1552. 36280 Vigo, Spain.
}

\begin{abstract}
SUMMARY: The recent failure of sardine catches off Galicia (NW Spain), an area where landings reached up to 100 thousand tonnes only a few years ago, may be explained by two possible hypotheses. The "depletion" hypothesis states that diminishing sardine catches were due to a decrease in stock biomass resulting from a combination of reduced recruitment and increased fishing mortality. The "change in distribution" hypothesis states that catch failure was due to a change in the distribution of the stock owing to environmental changes. Available information, based on direct observations from acoustic and ichthyplankton surveys and the fishery, was analysed. When the stock size is high, the spawning area of the sardine extends offshore in the Cantabrian Sea, and spreads along the continental shelf off northern Portugal. Moreover, adult fish undertake feeding migration towards Galician waters. This spawning behaviour results in a recruitment located mainly off Portugal. Low stock size causes a shrinkage in the distribution area throughout coastal waters and in the Cantabrian Sea, reaching the inner part of the Bay of Biscay. This process also affects the migration range and favours a higher retention in coastal waters of the early life stages (from eggs to recruits), which remain primarily in the same area where they were hatched. The lack of sardine in Galicia may be explained by a depletion process which affects both the feeding migration of adult fish and the recruitment occurrence off southern Galicia. This paper also analyses the dynamics of this stock in the context of a metapopulation. Taking this concept into consideration, we also examined the influence of the dynamics of each sub-population and the environmental conditions that might affect the success of the recruitment.
\end{abstract}

Key words: sardine, stock variability, recruitment, Iberian peninsula, metapopulation.

\section{INTRODUCTION}

Sardine, pilchard and anchovy stocks form the basis of commercially important fisheries which are closely related to high-productivity areas. For these fish species, the stock area and distribution are correlated with abundance, and are dependent upon the environmental regime (Lluch-Belda et al., 1989). Favourable regimes are prolonged periods (a decade or longer) of propitious environmental conditions

\footnotetext{
*Received December 6, 2000. Accepted March 20, 2002.
}

over large geographic areas (Lluch-Belda et al., 1989, Schwartzlose et al., 1999). During these periods, better recruitment and growth as well as, perhaps, lower natural mortality rates and consequently higher yields are to be expected. In addition, during high abundance periods many stocks may undertake feeding and spawning migrations involving broader areas. Low abundance, reduced geographic distributions and low yields are associated with unfavourable regimes. Regime "shifts" are periods of transition, often abrupt, from one regime type to another. Regime shifts may not be immediately 


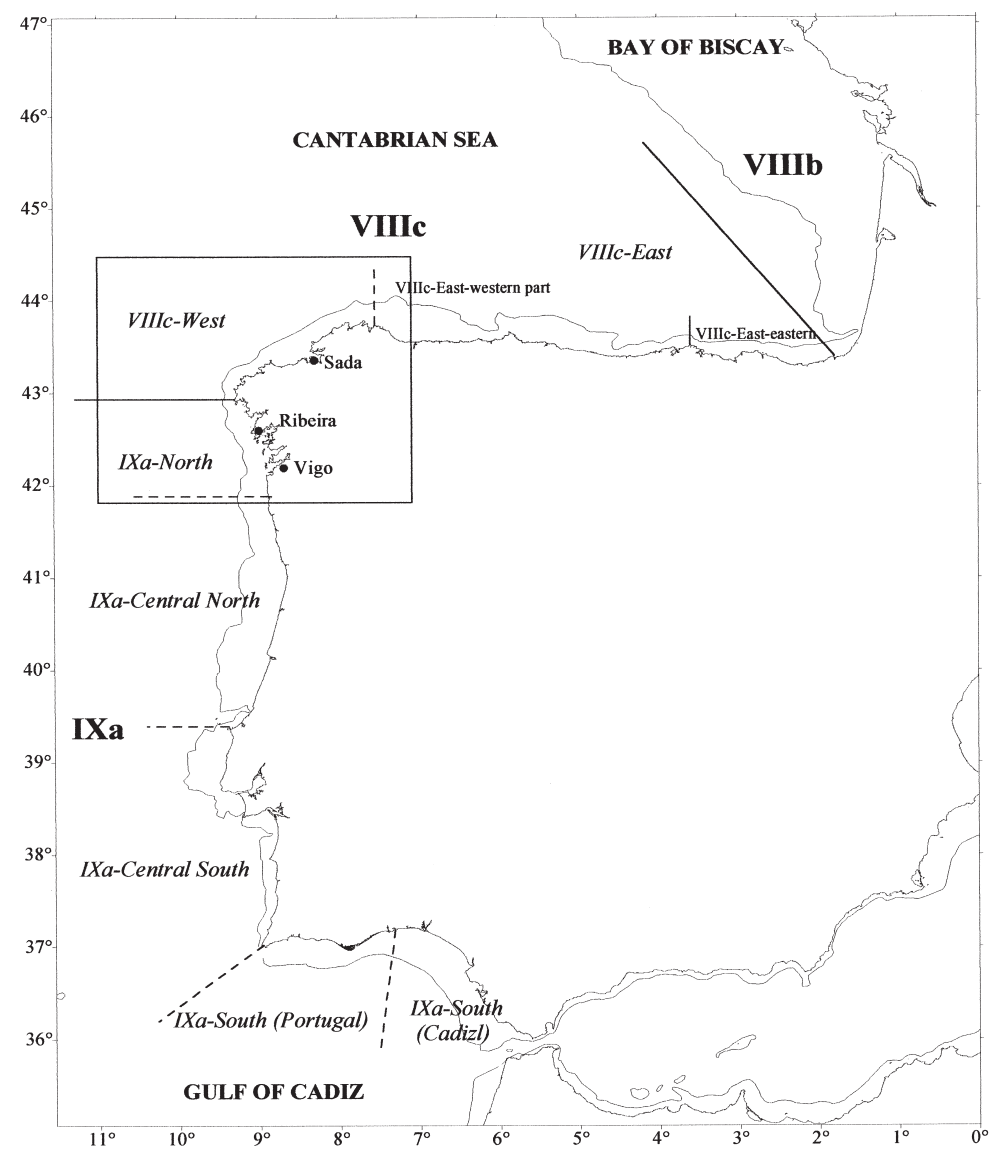

FIG. 1. - Studied area. Surrounded by a box, Galicia and the main location used in this work are shown.

recognisable in fisheries data because of delays in population (abundance) response, noise in data, problems with stock assessment models, or other difficulties. As these fish species are usually shortlived, the success of the recruitment process is crucial to further increase the size of the population. Clupeoid fishes show a high variability in the recruitment process, and hence in population size (Cole and McGlade, 1998). Variability in recruitment is related to the environmental conditions (Lasker, 1975; Cury and Roy, 1989; Bakun, 1996).

The Iberian Peninsula (Fig. 1) is located in the inner part of the Canary system and coastal upwelling occurs from March through October (Wooster et al., 1976; Blanton et al., 1984). In this area, sardine (Sardina pilchardus, Walb) have supported one of the oldest fisheries of both Portugal and Spain. The earliest documents of this activity on the Galician coast (northwestern corner of the Iberian Peninsula, see Fig. 1) date from the $14^{\text {th }}$ century (Ferreira, 1998). The development of the sardine fishery was closely related to an increase in the availability of this species together with a growing sea trade, particularly associated with the salt trade. Moreover, this development would appear to be related to an increase in the water temperature which occurred around 1350-70. Due to the abundance of sardine, the improvement in the salting procedures and trade routes, sardine became one of the most popular foods in this area. The earliest description of the sardine species on Galician coasts was recorded in the $18^{\text {th }}$ century (Cornide, 1788). Ever since the beginning of fishing activity, fluctuations in sardine abundance have been observed, based either on direct reports from the fishery or on the simple examination of salt consumption over the years. Earlier observations of sardine in Galician waters indicate that the presence of this fish species in the area did not depend only on the existence of a resident population but also on an overflow, which mainly occurred in summer. Movements of sardine were known and the species was initially caught using either drift nets or traps, which were placed along the main migratory routes (Ramalho, 1933). 
In order to manage the sardine population, extensive studies were started in the early seventies in Atlantic Iberian waters. Since no evidence was found to support the existence of different populations, these sardines were believed to belong to a single stock (Anon, 2000). However, the boundaries of this stock remain uncertain and are still a matter of concern. Spawning occurs in October-May in two main areas: off the coast of Portugal with a peak in winter; and in the Cantabrian Sea with a peak in spring (Re et al., 1990; Solá et al., 1990). The bulk of the recruits at age 0 is found off the northern coast of Portugal during summer and autumn. (Anon, 2000; Porteiro and Pestana, 1997). Although Galician waters are outside these main spawning areas and only the southern part of this region is located in the vicinity of the main recruitment area, sardine landings in Galicia are substantial, particularly during the middle of the year, which would suggest a feeding movement or migration. According to Fernandez and Navarro (1952) and Porteiro et al. (1986), there is an age gradient pattern from the Spanish/Portuguese border, where most of the fish are young, to the Cantabrian Sea where the bulk of the population belongs to older age groups.

Historically, the bulk of the catches were taken in northern Portugal and Galicia (i.e. ICES Sub-Divisions, IXa-North, IXa-Central North and VIIIcWest), as shown in Figure 2. Although in this figure the catches from VIIIc are aggregated, most of them were allocated to VIIIc-West. In spite of the high variability observed in this time series, since 1985
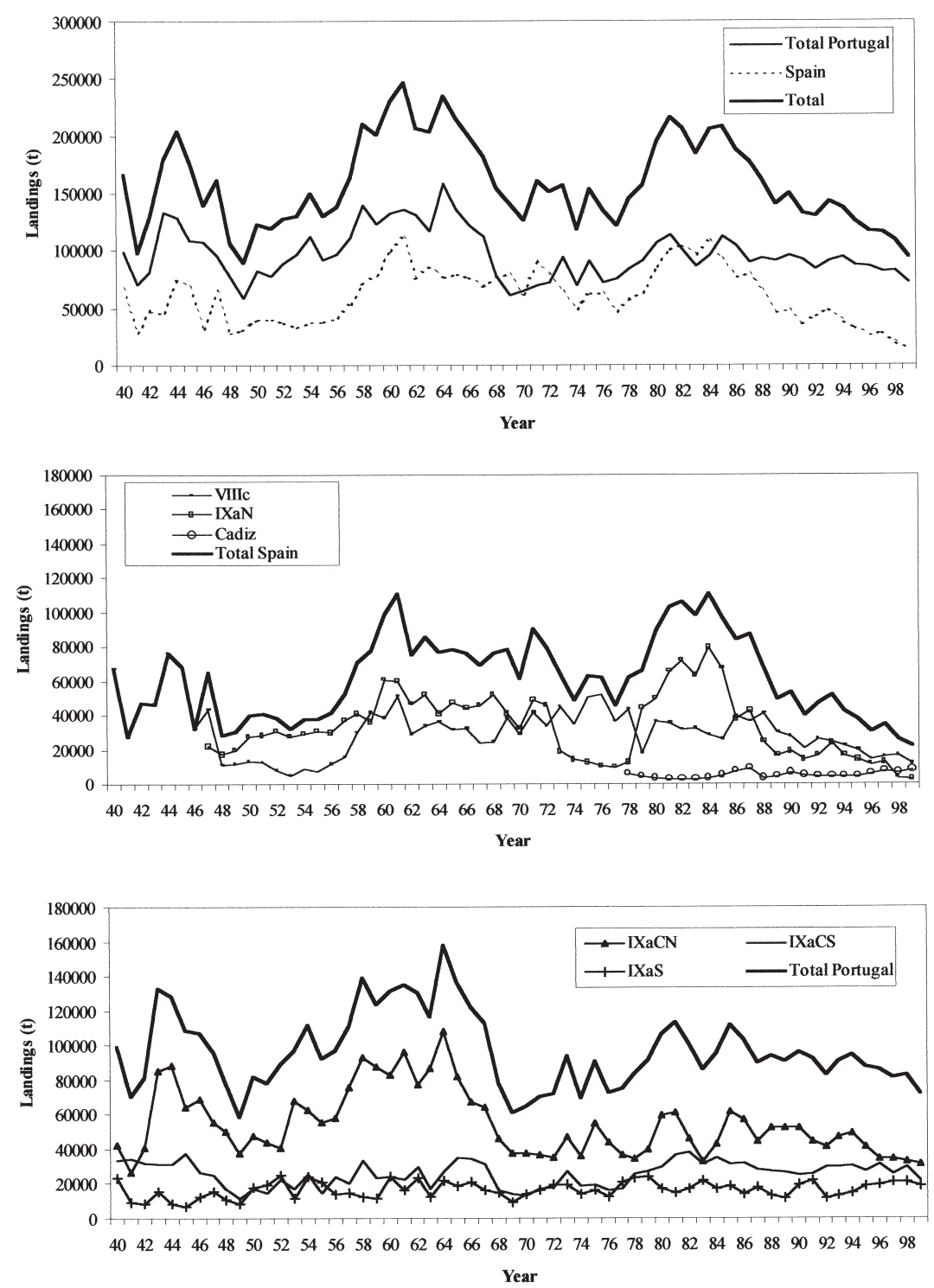

FIG. 2. - Annual landings of Iberian sardine since 1940. Above, landings by country; medium landings in the Spanish ICES Sub-Divisions; and below, landings in the Portuguese ICES Sub-Division 
there has been a declining trend in the catches from this area, with the lowest values of the time series in Galicia (IXa-N and VIIIc-West) being reached in recent years. This decline was considerable in IXaNorth where the catches in 1998 and 1999 only reached 3.7 and 2.5 thousand tonnes respectively.

In order to explain the disappearance of the sardine from one of its traditional feeding areas, the available information on this stock was re-examined. This paper summarises the available data and discusses possible causes for the decline in catches off NW Spain in recent years.

\section{MATERIAL AND METHODS}

\section{Sardine landings off Atlantic Galician waters}

Landings from the most important harbours in Galicia, Vigo, Ribeira and Sada (Fig. 1), recorded since 1988, were analysed. The fleet is composed of purse seiners (around 280 boats, with an average GRT of 29 tonnes in the early seventies, increasing to 48 tonnes in the nineties). Sardine is the target fish species of these fleets, especially the larger ones. For the purpose of stabilising prices and decreasing fishing effort, starting in 1990 a number of management measures were introduced. A daily maximum allowable catch of $10,000 \mathrm{~kg} /$ fishing day until 1996, which was decreased by $1,000 \mathrm{Kg} /$ fishing day per year until 1999 to reach 7,000 kg per fishing day and a weekly limitation in the number of fishing days (5 days per week) are some of the measures that were implemented. Because catches are landed daily, these fleets have a short displacement range (i.e. no more than $30 \mathrm{~nm}$ away from the harbour). Thus, their catches are roughly representative of the local sardine abundance around each location.

\section{Spawning grounds}

Stock size is related to the extension of the spawning area (Deriso et al., 1996), which can be estimated in a given zone by the presence/absence of eggs in the surveyed area (Augustin et al., 1996; Borchers et al., 1997). Sardine egg distribution was analysed using direct sardine surveys (whole coverage in 1998, 1997 and 1999, and partial coverage of the Spanish continental shelf in 1990) and other egg surveys targeting different fish species (i.e. mackerel and horse mackerel). Spawning grounds and egg information were thoroughly analysed in Bernal
(1999) and Stratoudakis (1999) and we will refer to the most important findings of these works.

\section{Stock size}

Direct estimation of stock size is provided by both acoustic and daily egg production (DEP) surveys. Acoustic surveys are routinely carried out by both countries using the same survey methodology and data analysis (Anon 1997). Spain began to conduct acoustic surveys in the summer of 1983, but only those performed in spring were analysed, these data being available between 1986 and 1999 with no surveys in 1989 and 1994. Since 1997 the surveys have also covered the south of the French continental shelf. Portugal has undertaken surveys in spring, summer and fall. For this study, the fall and spring time survey series were analysed. The fall time series starts in 1984, but shows gaps between 1988 and 1991 and from 1993 to 1996 . The Portuguese spring time series starts in 1986 but there are gaps between 1989 and 1994 and in 1987. As of 1995 the area covered was extended southward to the Gulf of Cadiz. Annual landings by the ICES Sub-Division, provided for analytical assessment purposes (Anon., 2001), were used to calculate crude estimates of relative exploitation rates based on catch and survey data without using the stock assessment model as estimated at the ICES. An availability index was formulated as follows:

$$
A I=1-(\log (\rho) / \log (\psi))
$$

where $\psi$ is the fish abundance (number of fish at age $1+)$ in a given ICES Sub-Division estimated by the acoustic surveys performed in spring and $\rho$ is the total catch in number obtained in this area. A positive index suggests that the sardine availability in number in spring estimated by the acoustic surveys in a given area is high enough to maintain the fishery during the whole year. In contrast, a negative index in a given area is an indication of an increase in the availability of sardine in this area.

\section{Formulation of hypothesis}

The recent failure of sardine fisheries in Galician Atlantic waters is analysed on the basis of two hypotheses: i) The Ibero-Atlantic stock of sardine is immersed in a depletion process; and ii) The IberoAtlantic stock of sardine has changed its main distribution area. 
The "depletion" hypothesis states that reductions in sardine catch and biomass, especially off Spain, are due to a decrease in stock biomass resulting from a combination of reduced recruitment and increased fishing mortality, particularly of older fish. To formulate this hypothesis, the Iberian sardine stock distribution is assumed to be centred in the south, off Portugal, with another smaller area located in Cantabrian waters. Therefore, if the abundance diminishes in the stock as a whole, the geographic area shrinks towards the south (i.e. Portugal), leading to an increase in the abundance of older ages in this area. If this is true, the abundance indices based on Portuguese data and catch off Portugal should be relatively constant because the density and area occupied by the sardine have changed very little. Declines in catch and abundance indices based on Portuguese data are not likely to occur unless the sardine stock biomass and area become further diminished.

The "change in distribution" hypothesis states that reductions in catch and biomass off Spain were due to a change in the distribution of the stock relat-
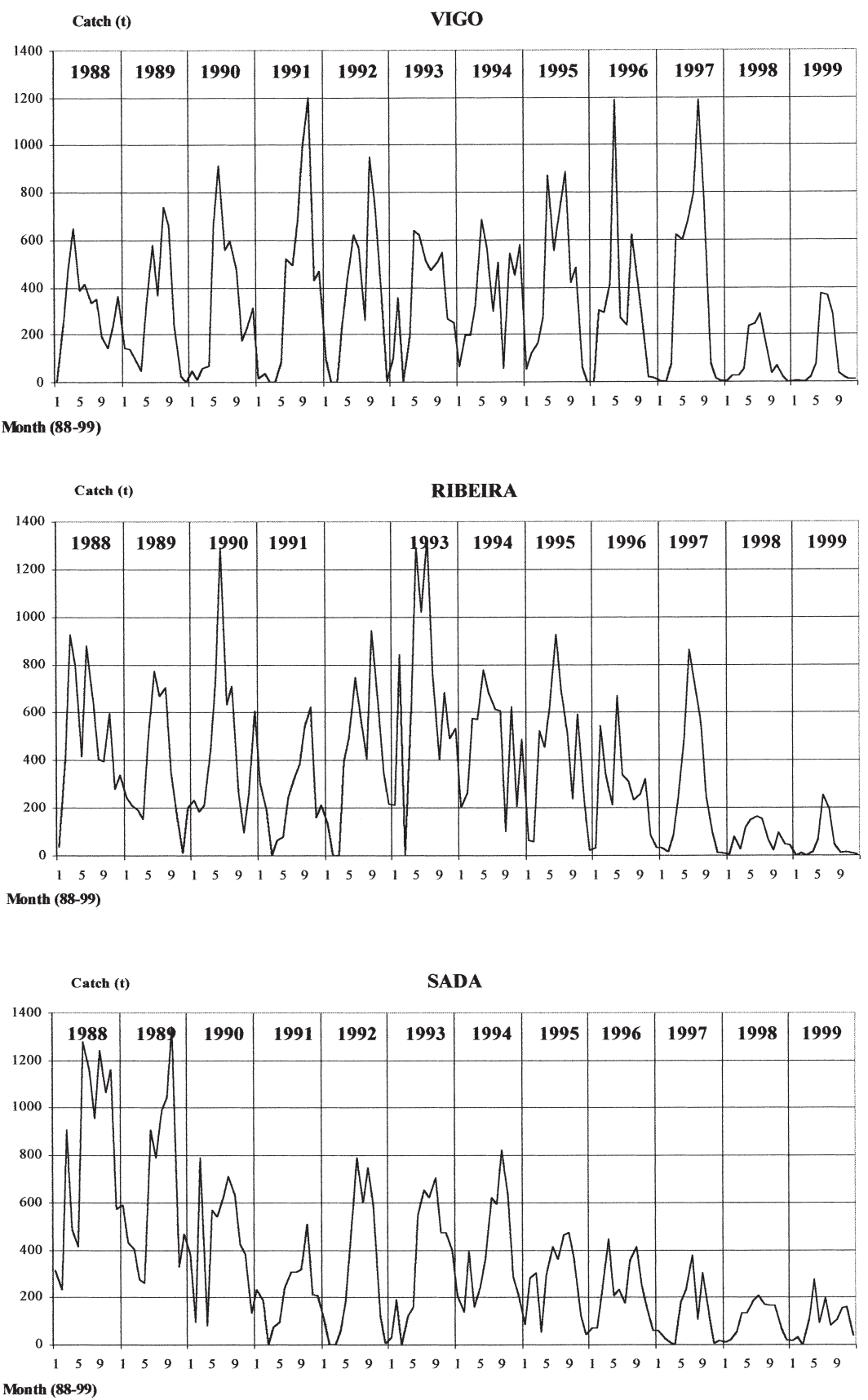

FIG. 2. - Monthly sardine landings in the main Galician harbours. 
ed to environmental changes that may not have affected stock productivity. According to this hypothesis, no evidence of changes in stock size will be found and the fluctuations in catches are mainly linked to the availability of fish.

\section{RESULTS}

\section{Sardine landings off Atlantic Galician waters}

Monthly catches from Vigo, Ribeira and Sada since 1988 are shown in Figure 3. During 1991-93 there was a closure period of 45 days in MarchApril. In 1998 and 1999 landings in these harbours were almost negligible. In Sada there was a continuous decreasing trend over the time series. On the other hand, in both Vigo and Ribeira sardine landings showed a sharp decrease from 1997 to 1998. An analysis of the landings revealed the existence of an occasional winter fishery, especially in Sada and Ribeira. In Ribeira, this winter fishery took place one year after the occurrence of a good year class. For instance, 1987, 1991 and 1992 had good year classes and winter sardine catches occurred in this harbour in 1988 and during 1992 and 1993. In Sada, the winter fishery appeared to occur two years after a good year class.

As expected, fish availability and catches increased in summer in all harbours.

\section{Spawning grounds}

A significant reduction in the spawning area was observed in the Spanish zone (Bernal, 1999). A drastic reduction occurred off the Galician area, dropping from around $7000 \mathrm{~km}^{2}$ estimated in both 1988 and 1990 to only $523 \mathrm{~km}^{2}$ estimated in 1997. Moreover, in this region, zero probability of the presence of eggs was predicted for 1997 (Bernal, 1999). In the Cantabrian Sea, there was also a major decline from around $10000 \mathrm{~km}^{2}$ in 1988 and 1990 to only $3000 \mathrm{~km}^{2}$ in 1997 . The inner part of the Bay of Biscay showed a significant decrease from 1988 to $1990\left(4600 \mathrm{~km}^{2}\right.$ to $\left.2985 \mathrm{~km}^{2}\right)$, while no major changes occurred from 1990 to $1997\left(2351 \mathrm{~km}^{2}\right)$. Whereas in the late eighties eggs were distributed throughout the continental shelf and offshore, in the late nineties the spawning area off the Spanish coast was restricted to shallower waters. There was a shrinkage process of the spawning area along the coastal waters of the inner part of the Bay of Biscay. Moreover, an overall reduction in batch fecundity and average weight of females accomplished this process (Pérez et al., 1989; García et al., 1991; Lago de Lanzós et al., 1998). In Portuguese waters, there was a significant reduction of the spawning area (Stratoudakis, 1999). In the late eighties the spawning area was twice the size of the area left in the late nineties. Nevertheless, a drastic reduction only occurred in the northern area, while the southern part remained practically stable at around $4500 \mathrm{~km}^{2}$. Unlike the case of Spain, off Portugal, the batch fecundity increased (Cunha et al., 1992 and 1997).

\section{Stock size}

Spawning stock biomass and recruitment as estimated by the ICES Working Group on the Assessment of Sardine (ICES 2000) are shown in Figures 4

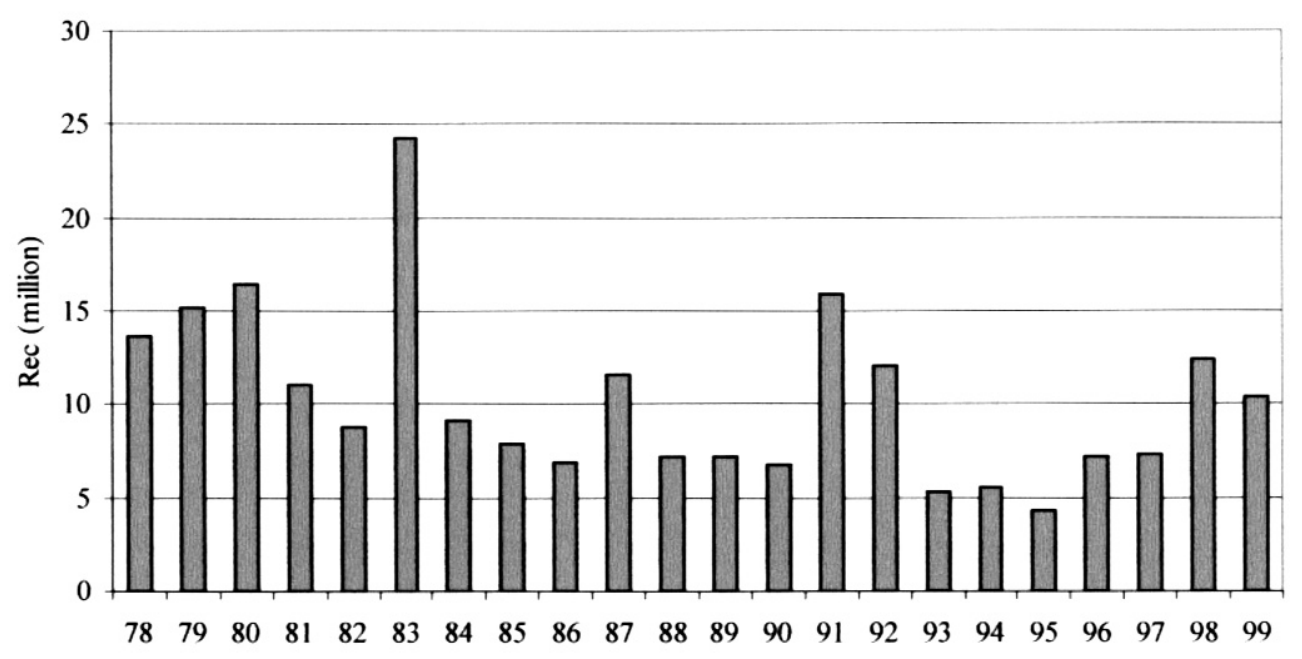

FIG. 4. - Estimated recruitment at age 0 from Anonymous (2001) 


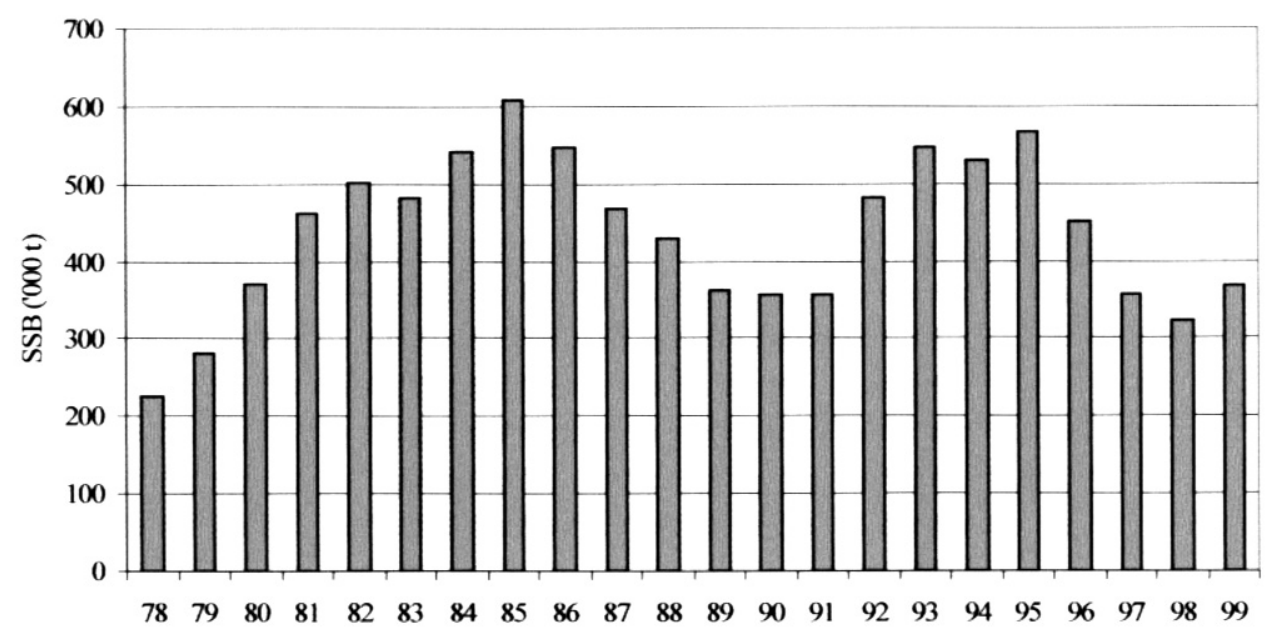

FIG. 5. - Estimated Spawning Stock Biomass from Anonymous (2001)

and 5. Although the absolute values might be biased because of uncertainties in the overall accuracy of the model (see Anon., 2001 for further explanations), trends are quite similar regardless of the input time series used in tuning the model and making assumptions (i.e. separable periods). Spawning Stock Biomass (time series from 1977 to 1999) shows two peaks situated in the mid-eighties and the mid-nineties which were followed by periods of low stock size occurring in the late eighties and late nineties. Recruitment at age 0 in 1978-81, 1983, 1987, 1991-92 and 1998 was above the geometric mean of the time series. The lowest estimated recruitment occurred during the period 1993-95. The exploitation pattern has changed over the time series. In the early eighties most of fish caught belonged to younger age groups (i.e. age groups 0,1 and 2). Since then, the contribution of younger fish in the catch-at-age matrix has decreased. According to Azevedo (1999), this change has occurred mainly off the southern region of Portugal.

The availability indices are shown in Table 1 and Figure 6. There was a significant decrease in the number of fish estimated by acoustic surveys off northern Galicia. Low estimates occurred in 1996 and 1998 and are 100 times lower than estimations from the eighties. In Cantabrian waters (ICES SubDivision VIIIc-East) the number of fish also decreased but since 1996 it has remained fairly stable. In southern Galicia (ICES Sub-Division IXa-N) the number of fish estimated in spring was always lower than in the other regions and reached its lowest value in 1999. Off Portugal there seemed to be an overall decrease from the late eighties to the late nineties. Nevertheless, since 1996 there has been a relatively stable situation, with the only noticeable

TABLE 1. - Number of fish caught in the year ( $C$, in million fish), estimated number fish from spring acoustic survey (when available, $S$. est. in million fish), and availability index ( $I$, when available) for each year and area.

\begin{tabular}{|c|c|c|c|c|c|c|c|c|c|c|c|c|c|c|c|c|c|c|c|c|c|c|}
\hline \multirow[b]{2}{*}{ YEAR } & \multicolumn{4}{|c|}{ IXa-Ca } & \multicolumn{3}{|c|}{ IXa-S } & \multicolumn{3}{|c|}{ IXa-CS } & \multicolumn{3}{|c|}{ IXa-CN } & \multicolumn{3}{|c|}{ IXa-N } & \multicolumn{3}{|c|}{ VIIIc-W } & \multicolumn{3}{|c|}{ VIIIc-E } \\
\hline & $C$ & $S$. & & $I$ & $C$ & $S e$ & st. & $C$ & $S e$ & st. & $C$ & Ses & $I$ & $C$ & Se & st. & $C$ & Ses & st. & $C$ & Ses & $s t$. \\
\hline 1986 & 189 & na & & na & 339 & 2522 & 0.2562 & 638 & 2522 & 0.1922 & 1154 & 3427 & 0.1337 & 678 & 105 & -0.4006 & 312 & 716 & 0.1263 & 3881 & 1490 & 0.1839 \\
\hline 1987 & 190 & na & & na & 439 & na & na & 653 & na & na & 1054 & na & na & 933 & 337 & -0.1748 & 384 & 3315 & 0.2656 & 4191 & 1498 & 0.1741 \\
\hline 1988 & 116 & na & & na & 429 & 1274 & 0.1521 & 586 & 1274 & 0.2158 & 11271 & 10164 & 0.2382 & 373 & 172 & -0.1496 & 310 & 1185 & 0.1892 & 326 & 802 & 0.1345 \\
\hline 1989 & 89 & na & & na & 286 & na & na & 506 & na & na & 1051 & na & na & 296 & na & na & 288 & na & na & 259 & na & na \\
\hline 1990 & 151 & na & & na & 434 & na & na & 473 & na & na & 1014 & na & na & 290 & 134 & -0.157 & 175 & 496 & 0.1676 & 239 & 490 & 0.1158 \\
\hline 1991 & 100 & na & & na & 447 & na & na & 629 & na & na & 1215 & na & na & 660 & 152 & -0.2909 & 166 & 49 & -0.3087 & 1261 & 1232 & 0.3195 \\
\hline 1992 & 90 & na & & na & 231 & na & na & 569 & na & na & 881 & na & na & 489 & 203 & -0.1645 & 282 & 100 & -0.2242 & 125 & 300 & 0.1527 \\
\hline 1993 & 71 & na & & na & 270 & na & na & 622 & na & na & 934 & na & na & 457 & 380 & -0.0309 & 290 & 142 & -0.1434 & 1011 & 1667 & 0.3766 \\
\hline 1994 & 69 & na & & na & 266 & na & na & 596 & na & na & 785 & na & na & 260 & na & na & 202 & na & na & 93 & na & na \\
\hline 1995 & 79 & na & & na & 321 & na & na & 491 & na & na & 618 & na & na & 195 & na & na & 124 & na & na & 107 & na & na \\
\hline 1996 & 85 & 3522 & 0.45 & 553 & 327 & 2148 & 0.2452 & 634 & 2148 & 0.184 & 757 & 1036 & 0.0451 & 159 & 209 & 0.0509 & 100 & 15 & -0.6884 & 71 & 519 & 0.3166 \\
\hline 1997 & 124 & 3558 & & 0.41 & 393 & 1904 & 0.2087 & 484 & 1904 & 0.2482 & 707 & 4759 & 0.2251 & 294 & 115 & -0.198 & 90 & 59 & -0.1041 & 138 & 521 & 0.2115 \\
\hline 1998 & 224 & 2279 & 0.29 & 998 & 371 & 1281 & 0.1729 & 535 & 1281 & 0.2192 & 781 & 4750 & 0.2132 & 77 & 247 & 0.2109 & 77 & 14 & -0.6272 & 138 & 511 & 0.2093 \\
\hline
\end{tabular}



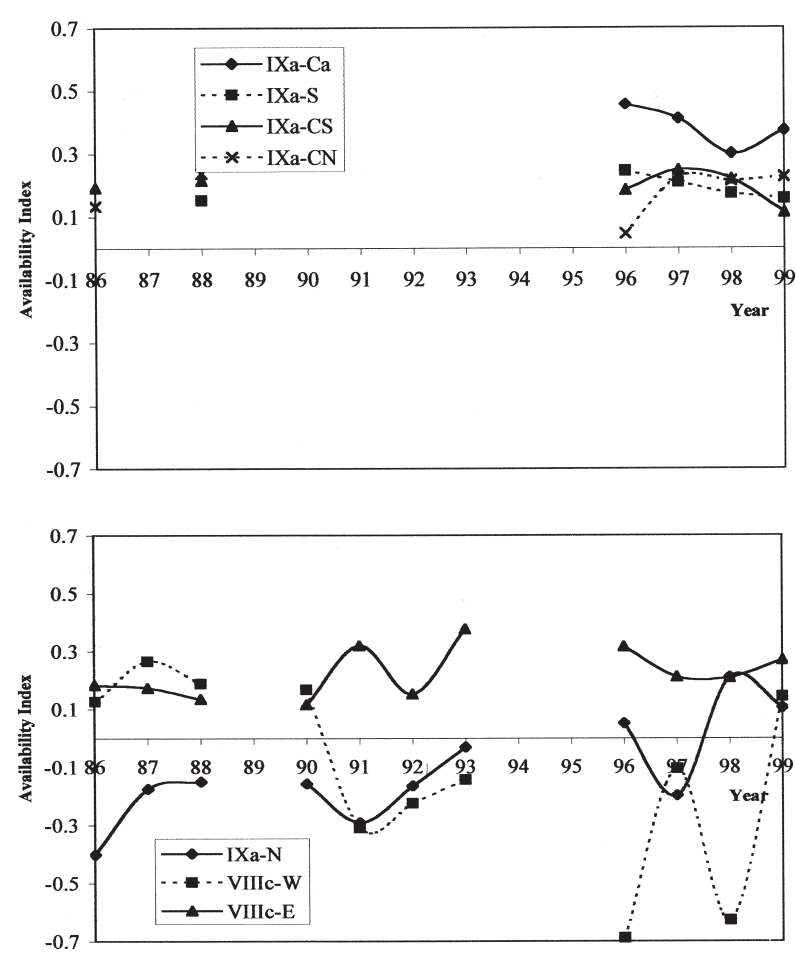

FIG. 6. - Availability index. Above, southern areas; below, northern areas.

occurrence being the decrease in the southern areas of Portugal, which was compensated for by a substantial increase in Cadiz. Temporal changes in this area were analysed by Morais et al. (1999), who concluded that changes in fish abundance in each area are significant from winter to spring.

Fish movements are assumed to occur when the availability index in a given area is negative (i.e. the number of fish caught during the year is higher than the number available in the fishery in spring). Accordingly, most of the catches in southern Galicia were taken from migrating fish (negative availability index, Table 1). In northern Galicia, these movements were also detected when the number of fish, as estimated by acoustic surveys, started to decrease in 1991. In recent years the availability of fish in Galicia has been extremely low and the sardine fleet has changed either its target fish species (i.e. horse mackerel) or its fishing grounds by changing harbours. This could explain the change in the availability index which occurred in these areas most recently. In the other areas, no fish movements could be derived from the availability index, as it was consistently positive. Nevertheless, it should be noted that in both IXa-Cádiz and VIIIc-E, sardine is not an important target species, and therefore their catches did not reflect the local abundance.

\section{DISCUSSION}

The decline in the Spawning Stock Biomass observed since the mid-nineties is the result of a diminishing spawning area. This shrinkage in the spawning area was located mainly off northern Portugal and in the western part of the Cantabrian Sea. Together with this reduction, a considerable decline in Galician catches occurred in the late nineties, but there was a fairly stable yield off southern Portugal and in the eastern part of the Bay of Biscay.

\section{The regime problem}

Schwartzlose et al. (1999) analysed the synchrony of the catch trends in several populations of sardines and anchovies. They found a strong positive correlation between sardine catches in the PeruChile system, off Japan and California. Food and temperature were identified as the most suitable mechanisms for shifts in regime.

Sea surface temperature (SST) has increased off the Iberian Peninsula in recent years (Lavin et al., 1998; Dias et al., 1992; 1996). Noto and Yasuda (1999) found that the natural mortality from the postlarval stage to age 1 in the Japanese sardine was positively correlated with sea surface temperature. They related the increase in the population size to the low SST period which occurred during 19701980, leading to a decrease in the natural mortality of earlier life stages. Unlike the Japanese sardine, the sardines in the Humbolt system have expanded in warm periods (Lluch-Belda et al., 1992), although no relationship between sardine recruitment and temperature was found (Serra et al., 1998). In the Bay of Biscay, both sardine distribution and abundance have increased in the last few years (Massé, pers. com.) as opposed to the trend observed in the Cantabrian Sea. Given the contradictory trajectory of the two neighbouring populations, the effect of the increasing trend in sea surface temperature on stock productivity is still unknown.

Primary production off Galicia is high, reaching values of up to $7.4 \mathrm{C} \mathrm{m}^{-2} \mathrm{~d}^{-1}$ (mean value of $4.3 \mathrm{C} \mathrm{m}^{-2}$ $\mathrm{d}^{-1}$ ) during upwelling events (Teira et al., 2000, in press). Even without upwelling events, the primary production is also high and may exceed $1.6 \mathrm{C} \mathrm{m}^{-2} \mathrm{~d}^{-1}$ (Bode and Varela, 1998). For instance, values of 2.6 $\mathrm{C} \mathrm{m}^{-2} \mathrm{~d}^{-1}$ were measured in the Canary system (Estrada, 1980). Off northern Galicia microflagellates constituted the bulk of the phytoplankton followed by the diatoms (Casas et al., 1999). It should 
TABLE 2. - Summary statistics for the daily upwelling index from 1987 to 1998

\begin{tabular}{|c|c|c|c|c|c|c|c|c|c|c|c|c|}
\hline & 1987 & 1988 & 1989 & 1990 & 1991 & 1992 & 1993 & 1994 & 1995 & 1996 & 1997 & 1998 \\
\hline Min & -3682 & -3891 & -2398 & -7564 & -8776 & -2578 & -3767 & -4892 & -5664 & -4397 & -3676 & -4871 \\
\hline 1 st Qu. & -593 & -468 & -259 & -570 & -332 & -201 & -485 & -456 & -385 & -482 & -472 & -428 \\
\hline Mean & -173 & -30 & 31 & -177 & 27 & 145 & -81 & -69 & 4 & -138 & -172 & -65 \\
\hline Median & -53 & 93 & 84 & 41 & 148 & 116 & 12 & 44 & 169 & 16 & -80 & 21 \\
\hline 3rd Qu & 371 & 504 & 476 & 376 & 764 & 581 & 430 & 514 & 713 & 352 & 200 & 335 \\
\hline Max & 2325 & 3108 & 1861 & 2764 & 3382 & 2542 & 2955 & 1989 & 2845 & 2955 & 2306 & 3054 \\
\hline Total & 181 & 181 & 181 & 181 & 181 & 181 & 181 & 181 & 181 & 181 & 181 & 181 \\
\hline NA's & 0 & 0 & 0 & 0 & 0 & 0 & 0 & 0 & 0 & 0 & 0 & 0 \\
\hline Std Dev. & 998 & 1037 & 736 & 1372 & 1337 & 890 & 1079 & 1046 & 1302 & 1072 & 775 & 1134 \\
\hline
\end{tabular}

also be noted that the phytoplankton abundance in this area is higher than in the Cantabrian Sea. Sardines appear to be largely omnivorous, their diet ranging from phytoplankton (diatoms and dinoflagellates) to macrozooplankton (essentially copepods) and microzooplankton (nauplius copepods and tintinids) as well as pollen, judging from stomach contents (Oliver and Navarro, 1942; Varela et al., 1985).

Off northern Galicia, the primary production has not changed over the last decade. In addition, values here are higher than those recorded off North Africa. However, from 1989 to 1992, a decrease in the magnitude of diatom blooms as well as an increase in the abundance of microflagellates was observed off northern Galicia. Similarly, changes in dinoflagellate composition were observed in the early nineties in South Galicia (Cariño et al., 2000). As suggested by Corten (1999), changes in abundance and prevalence of zooplankton species might be caused by changes in water inflows which may affect the availability of fish. Nevertheless, given the wide variety of organisms consumed by the sardine and the stability of the primary production in this area, changes in the phytoplankton composition here would appear to be minor (Bode et al., 1994, 1996; Casas et al., 1997; Varela, 1992) and, therefore probably did not affect the availability of sardine in this area.

Relationships between recruitment and environmental conditions have been studied by several authors (Robles et al., 1992; Roy et al., 1994; Cabanas and Porteiro, 1998; Borges et al., 2000). Because of the extensive spawning period and different spawning grounds, the recruitment success of the sardine is the outcome of a long time/space integral. This reproductive strategy allows sardine to increase their chances of coming across a sequence of environmental events favourable to the survival and growth of the early life-history stages (Cole and McGlade, 1998). On the other hand, it makes it dif- ficult to link the recruitment to a particular oceanographic or climatic event. For instance, Table 2 and Figure 7 show the upwelling indices from 1987 to 1998 for the first half of each year as estimated by Lavín et al. (1991). Upwelling is derived from the atmospheric pressure information of a point located off the Galician coast $\left(43^{\circ} \mathrm{N}-11^{\circ} \mathrm{W}\right)$. The upwelling regime found in 1995 was similar to that observed in 1991 and 1992. However, the recruitment in 1991 and 1992 was well above the geometric mean of the time series whereas that of 1995 was the lowest (Table 2).

In keeping with our findings, the hypothesis regarding the change in distribution would appear to be unlikely. The losses of both stock area and size in the northern region were not compensated for by an
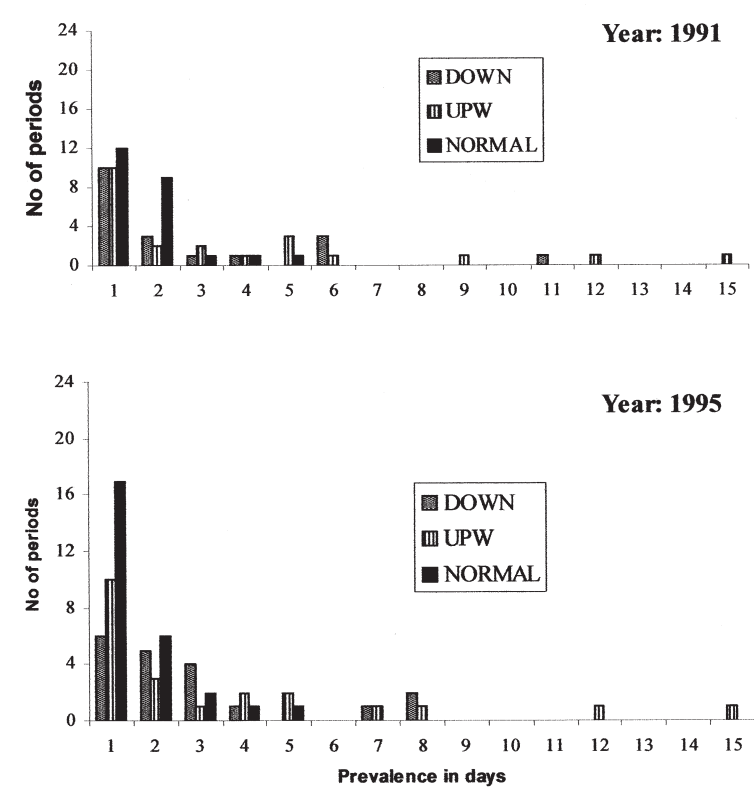

FIG. 7. - Index of prevalence (number of days with similar wind stress and direction) of upwelling events (-Qx measured in $\mathrm{m}^{3} / \mathrm{s}$ $\mathrm{km})$. Down, grouped number of periods of days with -Qx higher than $200 \mathrm{~m}^{3} / \mathrm{s} \mathrm{km}$; Upw, those lower than $-200 \mathrm{~m}^{3} / \mathrm{s} \mathrm{km}$; and Normal, those between 200 and $-200 \mathrm{~m}^{3} / \mathrm{s} \mathrm{km}$. 
increase in the southern region. Moreover, either the increase in sea surface temperature or possible changes in food availability may have affected the overall productivity of the stock. However, since a clear displacement of the stock was not detected, it might be concluded that the lack of sardine off Galicia over the last two years was not caused by a displacement of the bulk of the stock towards southern areas.

\section{Population dynamics and identity}

The location of the main area for recruits at age 0 centred off North Portugal was used as the principal basis to support the idea of a single population, although spawning occurs in two different locations (i.e. Cantabrian Sea and off Portugal), peaking in different periods (spring in the Cantabrian Sea and winter off Portugal). As reported by Fernández and Navarro (1952), the abundance of young sardine in the Cantabrian Sea was historically extremely low. This was confirmed in recent investigations on juvenile distribution around the Bay of Biscay (JUVESU, $2^{\text {nd }}$ intermediate report, 2000). A similar pattern was also observed in juvenile mackerel (Scomber scombrus). Mackerel spawn in spring throughout the Cantabrian Sea, close to the shelf break and both the number of adults and eggs or larvae off Portugal and South Galicia is low (SEFOS, final report 1995; Lago de Lanzós et al., 1993). In spite of this, the highest catches of juvenile mackerel occurred in South Galicia (JUVESU, $2^{\text {nd }}$ intermediate report, 2000). Although the mechanisms that led to this occurrence have not been studied in depth, this might be explained by wind-driven current responses. During late spring-summer predominant winds are N-NE (Blanton et al., 1984), causing a westward circulation in the Cantabrian Sea and resulting in upwelling off the western coast of the Iberian Peninsula. In the case of a NW wind, coastal circulation in the Cantabrian Sea is eastward, while there is a westward countercurrent close to the slope (Pingreee and Le Cann, 1989). According to this general pattern, larvae could reach the western part of the Iberian Peninsula and progress southward depending on the strength of the upwelling event.

However, since the mid-nineties, the reduction of the distribution area, which has occurred mainly in the NW part of the Iberian Peninsula (i.e. in Galician waters), has led to some uncertainties on stock identity. In our opinion, given the available information on recruitment, spawning and catches, the dynamics of the Ibero-Atlantic stock of sardine would seem to be better understood if the concept of metapopulation, as stated by McQuinn (1997) for the Atlantic herring, is adopted.

According to this concept, the structure of the sardine may be considered as an array of the local populations linked by variable degrees of gene flow (i.e. the Cantabrian sub-population and the Atlantic sub-population). Migration plays an important role in this concept because it is necessary for the survival, endurance and expansion of the metapopulation. In our case, when the two local populations (the Cantabrian and the Atlantic) achieved a large size, as observed during the eighties, older fish were predominant in the Cantabrian Sea and movements between both sub-populations were observed. During the spawning period, the sardine was spread out all over the continental shelf, reaching the Atlantic waters of northern Galicia. Moreover, eggs were even found offshore. Off northern Portugal spawning started earlier and was restricted to the continental shelf (Cunha et al., 1989). In southern Galicia, during the spawning period, only a few schools remained inside the "Rias" which are long, narrow estuaries. From April, with the increased availability of food, schools from northern Portugal moved northward, reaching Galician waters. Similarly, schools from the Cantabrian Sea moved westward, increasing the availability of the sardine off Galicia during the summer, and hence the maximum yield was achieved in this fishery in June-October. In addition, in southern Galicia recruitment at age 0 , which occurs mainly in summer, supports an important fishery on juveniles during this period. The high primary production off Galicia may act as a trigger mechanism forcing the sardine to undertake feeding migration to this area. Size- and age-related migrations (Nøttestad et al., 1999) might explain the age distribution pattern observed by Porteiro et al. (1986) along the Spanish coast.

Poor recruitment in the mid-nineties as well as an increase in fishing mortality due to a reduction in the overall stock size led to a shrinkage of the Cantabrian sub-population towards coastal waters in the western area (i.e. northwest corner of the Iberian Peninsula) and a fairly stable situation in the inner part of the Bay of Biscay. There was also a decrease in sardine distribution off northern Portugal and a movement of the Atlantic sub-population to the southern part of the Iberian Peninsula. The increase in older fish detected in the southern region of Portugal, both in catches and in acoustic surveys (Azevedo, 1999; Morais et al., 1999), as well as the 
TABLE 3. - Estimated mean age (left) and mean length $(\mathrm{cm})$ by area during the Spanish Spring acoustic surveys.

\begin{tabular}{|c|c|c|c|c|c|c|c|c|}
\hline & & & & & & $\mathrm{Me}$ & gth & \\
\hline & VIIIc-Ee & VIIIc-Ew & VIIIc-W & IXa-N & VIIIc-Ee & VIIIc-Ew & VIIIc-W & IXa-N \\
\hline 86 & 4.6 & 5.0 & 4.8 & 3.7 & 20.9 & 21.6 & 21.3 & 19.5 \\
\hline 87 & 5.6 & 5.5 & 4.7 & 3.1 & 22.3 & 22.2 & 20.6 & 18.5 \\
\hline 88 & 6.6 & 6.3 & 5.8 & 4.1 & 22.6 & 22.0 & 21.1 & 19.0 \\
\hline 89 & & & & & & & & \\
\hline 90 & 5.5 & 6.5 & 6.5 & 3.1 & 21.6 & 22.5 & 22.3 & 18.7 \\
\hline 91 & 5.6 & 6.0 & 5.2 & 3.5 & 19.6 & 21.8 & 22.6 & 21.8 \\
\hline 92 & 4.3 & 5.3 & 6.0 & 2.4 & 20.6 & 21.8 & 22.3 & 18.2 \\
\hline 93 & 7.4 & 6.9 & 3.6 & 2.2 & 23.1 & 22.8 & 20.2 & 18.4 \\
\hline 94 & & & & & & & & \\
\hline 95 & & & & & & & & \\
\hline 96 & 4.7 & 4.7 & 4.7 & 4.3 & 21.6 & 21.9 & 21.7 & 20.6 \\
\hline 97 & 3.4 & 3.7 & 4.8 & 3.7 & 20.6 & 20.8 & 21.9 & 19.7 \\
\hline 98 & 3.7 & 2.2 & 2.2 & 1.9 & 20.4 & 18.0 & 18.0 & 17.0 \\
\hline 99 & 3.2 & 3.7 & 2.5 & 2.8 & 18.2 & 21.0 & 18.5 & 18.5 \\
\hline
\end{tabular}

increase in batch fecundity in Portugal, agreed with this process. In the Cantabrian Sea, this process appeared to be gradual and hence catches in Sada also underwent a gradual decrease. In Table 3, mean age and mean length by ICES Sub-Division as estimated from the Spanish Spring acoustic survey are shown. Younger and smaller fish were consistently found in southern Galicia (IXa-N), whereas older specimens were located in the Cantabrian Sea (VIIIc-E). The poor recruitment from 1993 to 1995 increased the mean age in IXa-N estimated in 1996, which was quite similar over the surveyed area. When the spawning area in the Cantabrian Sea was restricted to coastal waters and the western part was abandoned (between 1997 and 1998), sardine also failed in southern Galicia. The occurrence of coastal spawning resulted in a retention of both eggs and larvae in shallower waters throughout Cantabrian waters. Fernández et al. (1991, 1993) and Varela (1996) explain the mechanism. In winter-spring the Cantabrian Sea is characterised by the presence of a poleward current (Frouin et al., 1990), which plays a crucial role as a barrier to the transport of eggs and larvae. In this context, the decrease in both mean age and length throughout the Cantabrian Sea, estimated during the acoustic surveys undertaken in 1998 and 1999 , concurred with the possible retention of larvae and small recruits in coastal waters. Off northern Portugal, the same situation might be suggested. From 1986 to 1999 the estimated spawning area was reduced from $8300 \mathrm{~km}^{2}$ to only $3100 \mathrm{~km}^{2}$, with the lowest surface area occurring in 1997 (only 1600 $\mathrm{km}^{2}$ ). Consequently, earlier life stages might have been retained in coastal waters without any northward progression. Furthermore, recent investigations off northern Portugal have indicated that sar- dine are restricted to coastal waters, and juveniles occurred mixed with adult fish, which creates problems in the normal evolution of the fishery.

The decrease in the stock area and stock size in northern areas has affected the movements of sardine, and at present it would appear that the spawning biomass in the Cantabrian is at a low level and virtually isolated from the northern Portuguese spawners. Moreover, the contribution of the Cantabrian spawners to the recruitment success off the western coast would now be negligible. Low gene exchange between both areas is expected at very low stock sizes. However, neither the northern Portuguese nor the Cantabrian spawning ground was completely abandoned. A recovery of any of these sub-populations will probably occur when a good incoming year class forces an expansion of the sardine distribution area. It should also be noted that the influence of upwelling or other oceanographic events, which take place mainly on the continental shelf, on recruitment success may depend on the size of the spawning area: the more coastal the distribution area the less important the influence of the oceanographic events will be. At low spawning stock sizes, continental conditions, such as river plumes, may play a more important role in recruitment success than the actual oceanic events. The location of the preferential areas of sardine in zones having major river plumes (i.e. the Douro-Aveiro area in Portugal and the Adour and surrounding Basque country rivers in the Cantabrian Sea) agree with this assumption.

From our point of view, the question of the failure of the Galician sardine fishery may be better understood in the context of depletion, especially regarding the northern population. The Atlantic sub- 
population also suffered a shrinkage process, but it was less intense than in the Cantabrian sub-population. Under these conditions, the bulk of the distribution remained off the southern area (Portugal), whereas in the northern area only a residual population was observed. The low size of the stock affected the distribution of fish; hence the lack of adult fish in Galician waters. On the other hand, coastal spawning behaviour resulted in the higher retention of earlier life stages (from eggs to recruits), which remain mainly in the same area where they were hatched. The lack of juveniles off southern Galicia may be explained by this mechanism.

Fréon and Misund (1999) reviewed the effect of the metapopulation on fisheries and stock assessment. The depletion of sub-populations is believed to cause long-term diminishing productivity. In the case of the Iberian sardine, sub-populations are mainly distributed in each country and Galician waters make up the area linking the two sub-populations, especially in summer. The interdependence of both sub-populations during periods of high stock sizes together with periods of virtual isolation at low stock sizes bring about major changes in spatial distribution, local abundance and age structure. Because of spatial changes in fish distribution and the shifts in the exploitation pattern owing to stock size, it is difficult to obtain a meaningful comparison between the stock size and the fishing mortality in the mid 1980s and the late 1990s, and to provide robust estimates of the state of the stock using the actual assessment model (Anon., 2000).

The actual knowledge on the Ibero-Atlantic sardine agrees with the concept of metapopulation. Nevertheless, there is still a lack of knowledge in terms of the relationship between the Iberian sardine and populations located in surrounding areas (i.e. the Bay of Biscay, Mediterranean Sea and Moroccan area). It is therefore necessary to carry out a multidisciplinary study including these areas in order to provide an holistic approach to stock identity. Furthermore, the assessment model should be modified to take into account the special features of stock dynamics (range of migrations, distribution, age structure, etc.) observed in a metapopulation.

\section{ACKNOWLEDGEMENTS}

Larry Jacobson helped us in an earlier document presented at the ICES Working Group. His comments, suggestions, and especially the discussions on the dynamics of pelagic fish, have allowed us to gain a more in-depth knowledge of the dynamics of the Iberian sardine. We are indebted to our colleagues, Manuela Azevedo, Yorgos Stratoudakis and Vitor Marques, who kindly provided the Portuguese data revision which has made this paper possible. We wish to thank the rest of the Scientific Team of Ipimar, Portugal, involved in sardine research projects, for their steadfast dedication to the study of this fish species over the last twenty years. We would also like to express our gratitude to our colleagues at the IEO. Miguel Bernal provided the revision of the egg surveys in the Spanish area. Some results from the SEFOS project (AIR2-CT93-1105) and JUVESU (FAIR CT97-3374) were also used. Finally, we are indebted to the anonymous referees who have greatly contributed to the improvement of the early manuscript.

\section{REFERENCES}

Anonymus. - 1997. Report of the Planning Group for Pelagic Acoustic surveys in ICES Sub-Areas VIII and IX, a Coruña, 3031 January 1998. ICES CM 1998/G: 2.

Anonymus. - 2000. Report of the Working Group on the Assessment of Mackerel, Horse Mackerel, Sardine and Anchovy. Copenhagen. ICES CM 2000/ACFM: 05 .

Anonymus. - 2001. Report of the Working Group on the Assessment of Mackerel, Horse Mackerel, Sardine and Anchovy. Copenhagen. ICES CM 2001/ACFM: 06.

Augustin, N.H., M.A. Mugglestone, and S.T. Buckland. - 1996. An autologistic model for the spatial distribution of wildlife. $J$. Appl. Ecol., 33: 339-347.

Azevedo, M. - 1999. Exploratory data analysis for Iberian sardine (Sardina pilchardus). WD Report of the Working Group on the Assessment of Mackerel, Horse mackerel Sardine and Anchovy. ICES CM 2000/ACFM: 5.

Bakun, A. - 1996. Patterns in the Ocean: Ocean processes and marine population dynamics. La Jolla. CA: California Sea Grant 323 pp.

Bernal, M. - 1999. Preliminary results on a two stage modelling of sardine (Sardina pilchardus, Walb) egg presence and abundance off the Spanish coast and its implication for stock assessment. WD. Report of the Working Group on the Assessment of Mackerel, Horse mackerel Sardine and Anchovy, ICES CM 2000/ACFM: 5

Borges, M.F., M. Santos, N. Crato, H. Mendes and B. Mota. - 2000. Sardine recruitment and climatic changes off Portugal in the last decades. WD Report of the Working Group on the Assessment of Mackerel, Horse Mackerel, Sardine and Anchovy. Copenhagen. ICES CM 2001/ACFM: 06.

Blanton, J. O., L. P. Atkinson, F. Fernández de Castillejo and A. Lavin Montero. - 1984. Coastal upwelling off the Rias Bajas, Galicia, Northwest Spain I: Hydrographic studies. Rapp. P.-v. Réun. Cons. Int. Explor. Mer, 183: 79-90.

Bode, A. and M. Varela. - 1998. Mesoscale estimations of primary production in shelf waters: a case study in the Golfo Artabro (NW Spain). J. Exp. Mar. Biol. Ecol., VOLUME NUMNBER: 111-131

Borchers, D.L., S.T. Buckland, I.G. Priede and S. Ahmadi. - 1997. Improving the precision of the daily egg production method using generalised additive models. Can. J. Fish. Aquat. Sci., 54: 2727-2742.

Cabanas, J.M. and C. Porteiro. - 1998. Links between the North Atlantic sardine recruitment and its environment (in press).

C. Cariño, E. Fernández, J. Mariño, M.J. Campos, Y. Pazos and J. 
Maneiro. - 2000. Long-term variability of dinoflagellate abundance in relation to decadal changes in atmospheric forcing. 31st Annual Symposium of the Estuarine and Coastal Sciences Association. Bilbao, 2000

Casas, B., M. Varela and A. Bode. - 1999. Seasonal succession of phytoplankton species on the coast of A Coruña (Galicia, northwest Spain). Bol. Inst. Esp. Oceanogr. 15(1-4): 413-429.

Cole, J. and J. McGlade. - 1998. Clupeoid population variability, the environment and satellite imagery in coastal upwelling systems. Rev. Fish Biol. Fish. 8: 445-471.

Cornide, J. - 1788. Ensayo de una Historia natural de los Peces y otras Producciones marinas de la costa de Galicia, arreglado al sistema del caballero Carlos Linné. Con un tratado de las diversas pescas y de las redes y aparejos con que se practican. A Coruña, 91-94.

Corten, A. - 1999. The reappearance of spawning Atlantic herring (Clupea harengus) on Aberdeen Bank (North Sea) in 1983 and its relationship to environmental conditions. Can. J. Fish. Aquat. Sci., 56: 2051-2061.

Cunha. M.E., I. Figueiredo, A. Farinha and M. Santos. - 1989. Estimation of sardine spawning biomass off Portugal by the daily egg production method. ICES CM 1989/H: 41

Cunha. M.E., I. Figueiredo, A. Farinha and M. Santos. - 1992. Estimation of sardine spawning biomass off Portugal by the daily egg production method. Bol. Inst. Espan. Oceanogr., 8: 139153

Cunha, M.E., V. Marques, E. Soares and A. Farinha. - 1997. Preliminary results from the joint sardine (Sardina pilchardus) DEPM and acoustic surveys in ICES Division IXa (Lat. $\left.41^{\circ} 50^{\prime} \mathrm{N}, 36^{\circ} 00^{\prime} \mathrm{N}\right)$ ICES CM 1997/Y:5

Cury, P. and C. Roy. - 1989. Optimal environmental window and pelagic fish recruitment process in upwelling areas. Can. J. Fish. Aquat. Sci., 46: 670-680

Días, C., E. Amorín and E.M. Das Dores Vacas. - 1992. Sea-surface temperature: seasonal variation between in the Iberian coast and the Madeira Islands. 1981-1987. ICES Mar. Sci. Symp. 195: 177-186

Dias, C.A., G. Pestana, E. Soares and V. Marques. - 1996. Present state of sardine stock in ICES Divisions VIIIc and IXa. WD ICES Working Group on the Assessment of Mackerel, Horse Mackerel, Sardine and Anchovy. Copenhagen, 1996. 45 pp.

Deriso, R.B., J.T. Barnes, L.D. Jacobson and P.R. Arenas. - 1996 Catch-at-age analysis for Pacific sardine (Sardinops sagax), 1983-1995. CalCOFI Rep., 37

Estrada, M. - 1980. Phytoplankton biomass and production in the upwelling region of NW Africa. Relationships with Hydrographic parameters. Mar. Biol., 60 63-71

Fernández, R. and F. De P. Navarro. - 1952. La sardina de Santander. Bol. Inst. Esp. Oceanogr., 55.

Fernández, E, A. Bode, A. Botas and R. Anadón. - 1991 Microplankton assemblages associated with saline fronts during a spring bloom in the Central Cantabrian Sea: differences in trophic structure between water bodies. J. Plankton Res., 13: 1239-1256

Fernández, E., J.L. Cabal, A. Acuña, A. Bode, J. Botas and C. García-Soto. - 1993 Plankton distribution across a slope currentinduced front in the southern Bay of Biscay. J. Plankton Res., 15: 619-641

Ferreira, E. - 1998. O Desenvolvemento da actividade pesqueira desde a alta Idade Media ó século XVII (Development of the fishing activity from the High Middle Age to the XVIIth Century). In Historia da Pesca en Galicia. Chapter II. Coordinated by Carmen Fernández Casanova.Servicio de Publicacións e Intercambio Científico da Universidade de Santiago de Compostela.

Fréon P. and O.A. Misund. - 1999. Dynamics of Pelagic Fish Distribution and Behaviour: Effects on Fisheries and Stock Asessment. Fishing News Books. Blackwell Science Ltd.

Frouin, R., A.F.G. Fiuza, I. Ambar and T. Boyd. - 1990. Observations of a poleward surface current off the coasts of Portugal and Spain during winter. J. Geophys. Res., 95: 679-691

García, A., N. Pérez, C. Porteiro and P. Carrera. - 1991. Estimates of the sardine spawning stock biomass off the Galician and Cantabrian coast. ICES CM 1991/H:35.

Lago de Lanzós, A., A. Solá, L. Motos and C. Franco. - 1993. Mackerel (Scomber scombrus, L) egg distribution and stage I egg production estimates in Division VIIIb,c and IXa-N in 1988, 1990 and 1992. ICES CM 1993/H:34
Lago de Lanzós, A., L. Quintanilla, A. Solá and C. Franco. - 1998. The egg production method applied to the spawning biomass estimation of sardine (Sardina pilchardus, Walb) in the northAtlantic Spanish coast. ICES CM 1998/BB:17

Lasker, R. - 1975. Field criteria for survival of anchovy larvae: the relation between inshore chlorophyll maximum layers and successful first feeding. Fish. Bull. US, 73: 453-462

Lavín, A., G. Diaz del Rio, J. M. Cabanas and G. Casas. - 1991. Afloramiento en el Noroeste de la Peninsula Iberica. Indices de afloramiento para el punto $43^{\circ} \mathrm{N} 11^{\circ} \mathrm{W}$. Periodo 1966-1989. Infor. Téc. Instit. Esp. Oceanogr., 91: 1-40.

Lavín, A., L. Valdés, J. Gil and M. Moral. - 1998. Seasonal and interannual variability in properties of surface water off Santander (Bay of Biscay) (1991-1995). Oceanlog. Acta, 21(2): 179-190

Lluch-Belda, D., R. J. M. Crawford, T. Kawasaki, A. D. MacCall, R. H. Parrish, R. A. Schwartzlose and P. E. Smith. - 1989. World-wide fluctuations of sardine and anchovy stocks: The regime problem. S. Afri. J. mar. Sci., 8: 195-205.

Lluch-Belda, D., D.B. Lluch-Cota, S. Hernández Vázquez and C.A. Salias-Zavala. - 1992. Sardine population expansion in eastern boundary sustems of the Pacific Ocean as related to sea surface temperature. In: A. Payne, K. Brink, K Mann and H Hilborn (eds), Benguela Trophic Functioning. S. Afr. J. mar. Sci. 12: $147-155$.

Morais, A., M.F. Borges and V. Marques. - 1999. Changes on Sardine distribution pattern and trends of recruitment spawning stock abundance in the Portuguese area as directly estimated by acoustic surveys from 1984-1999. WD Report of the Working Group on the Assessment of Mackerel, Horse mackerel Sardine and Anchovy, ICES CM 2000/ACFM:5

McQuinn, I.H. - 1997. Metapopulations and the Atlantic herring. Rev. Fish. Biol. Fish., 7: 297-329

Noto, M. and I. Yasuda. - 1999. Population decline of the Japanese sardine, Sardinops melanosticus, in relation to sea surface temperature in the Kuroshio Extensio. Can. J. Aquat. Sci., 56: 973983.

Nøttestad, L., J. Giske, J.C. Hols and A. Huse. - 1999. A lengthbased hypothesis for feeding migration in pelagic fish. Can. J. Aquat. Sci., 56(Suppl.1): 26-34.

Oliver, M and F. De P. Navarro. - 1952. Nuevos datos sobre la sardina de Vigo. Bol. Inst. Esp. Oceanog., 56.

Pérez, N., A. García, N. Lo and C. Franco. - 1989. The egg production method applied to the spawning biomass estimation of sardine (Sardina pilchardus, Walb) in the north-Atlantic Spanish coasts. ICES CM 1989/H:23.

Pingree, R.D., and B. Le Cann. - 1989. Celtic and Armorican slope and shelf residual currents. Prog. Oceanog., 23: 303-338

Porteiro, C., F. Alvarez, and J. A. Pereiro. - 1986. Sardine (Sardina pilchardus, Walb) stock differential distribution by age class in ICES Divisions VIIIc and IXa. ICES CM 1986/H:28.

Porteiro, C. and G. Pestana. - 1997. Atlantic Iberian sardine (Sardina pilchardus Walb.) WD GLOBEC/SPACC W.G. Dartmouth, June 1997

Ramalho, A. - 1933. Notice sur la pêche et quelques aspects de la biologie de la sardine au Portugal. Rapp. P.-v. Réun. Cons. Int. Explor. Mer, 84:29-40.

Ré, P., R. Cabral e Silva, E. Cunha, A. Farinha, I. Meneses and T. Moita. - 1990. Sardine Spawning off Portugal. Bol. Inst. Nac. Invest. Pescas, Lisboa 15: 31-44.

Robles, R., C. Porteiro and J.M. Cabanas. - 1992. The stock of Atlanto-Iberian sardine: possible causes of variability. ICES mar. Sci. Symp., 195: 418-423.

Roy, C., C. Porteiro and J.M. Cabanas. - 1995. The optimal Environmental Window Hypothesis in the ICES A Area: The example of the Iberian Sardine. ICES. Coop. Res. Rep. no 206.

Schawartzlose, R.A., J. Alheit, A. Bakun, T.R. Baumgartner, R. Cloete, R.J.M. Crawford, W.J. Fletcher, Y Green-Ruiz, E Hagen, T. Kawasaki, D. Lluch-Belda, S.E. Lluch-Cota, A.D. MacCall, Y. Matsuura, M.O. Neváez-Martínez, R.H. Parrish, C. Roy, R. Serra, K.V. Shust, M.N. Ward and J.Z. Zuzunaga. 1999. Worldwide large-scale fluctuations of sardine and anchovy populations. S. Afr. J. mar. Sci. 21: 289-347

Serra, R., P. Cury and C. Roy. - 1998. The recruitment of the Chilean sardine (Sardinops sagax) and the "optimun environmental window". In M.H. Durand, P. Cury, R. Mendelssohn, C. Roy, A. Bakun and D. Pauly (eds), Global versus Local Changes un Upwelling Systems, pp. 267-274. ORSTOM, Paris. 
Solá, A., L. Motos, C. Franco and A. Lago. - 1990. Seasonal occurrence of pelagic fish eggs and larvae in the Cantabrian sea (VIIIc) and Galicia (Ixa) from 1987 to 1989. ICES, C.M. 1990/H:25.

Stratoudakis, Y. - 1999. Temporal changes in estimated spawning area and distribution of sardine (Sardina pilchardus) eggs off Portugal WD. Report of the Working Group on the Assessment of Mackerel, Horse mackerel Sardine and Anchovy, ICES CM 2000/ACFM:5

Teira, E., P. Serret and E. Fernández. - 2000. Phytoplankton sizestructure, particulate and dissolved organic carbon production and oxygen fluxes through microbial communities in the NW
Iberian coastal transition zone. Mar. Ecol. Prog. Ser., (in press) Varela, M., A. Larrañaga, E. Costas and B. Rodríguez. - 1988. Contenido estomacal de la sardina (Sardina pilchardus, Walb) durante la campaña Saracus 871 en las plataformas Cantábrica y de Galicia en febrero de 1987. Bol. Inst. Esp. Oceanogr. 5(1): $17-28$

Varela, M. - 1996. Phytoplankton ecology in the Bay of Biscay. Sci. Mar. 60(Supl. 2) 45-53.

Wooster, W.S., A.S. Bakun and D.R. McLain. - 1976. The seasonal upwelling cycle along the eastern boundary of the North Atlantic. J. Mar. Res., 36(2): 131-141. 